\title{
Perspective
}

\section{Rescue Therapies for H. pylori Infection in Italy}

\author{
Vincenzo De Francesco ${ }^{1, *}$, Angelo Zullo ${ }^{2}$, Luigi Gatta ${ }^{3}{ }^{\circ}$, Raffaele Manta ${ }^{4}$, Matteo Pavoni ${ }^{5}(\mathbb{D}$, \\ Ilaria Maria Saracino ${ }^{5}{ }^{\circ}$, Giulia Fiorini ${ }^{5}$ and Dino Vaira ${ }^{5}$ \\ 1 Gastroenterology Unit, 'Riuniti’ Hospital, 71122 Foggia, Italy \\ 2 Gastroenterology and Digestive Endoscopy, Nuovo Regina Margherita Hospital, 00153 Rome, Italy; \\ angelomario.zullo@aslroma1.it \\ 3 Gastroenterology and Endoscopy Unit, Versilia Hospital, 55049 Lido di Camaiore, Italy; gattalg@gmail.com \\ 4 Gastroenterology and Digestive Endoscopy, 'Generale' Hospital, 06129 Perugia, Italy; r.manta@libero.it \\ 5 Department of Medical and Surgical Sciences, S. Orsola Hospital, University of Bologna, 40138 Bologna, Italy; \\ matteo.pavoni@studio.unibo.it (M.P.); ilariamaria.saracino@studio.unibo.it (I.M.S.); \\ giulia.fiorini@aosp.bo.it (G.F.); berardino.vaira@unibo.it (D.V.) \\ * Correspondence: vdefrancesco@alice.it; Tel.: +39-0881-733776; Fax: +39-0881-732092
}

Citation: De Francesco, V.; Zullo, A.;

Gatta, L.; Manta, R.; Pavoni, M.; Saracino, I.M.; Fiorini, G.; Vaira, D. Rescue Therapies for H. pylori Infection in Italy. Antibiotics 2021, 10, 525. https://doi.org/10.3390/ antibiotics 10050525

Academic Editor: Nicholas Dixon

Received: 23 March 2021

Accepted: 27 April 2021

Published: 3 May 2021

Publisher's Note: MDPI stays neutral with regard to jurisdictional claims in published maps and institutional affiliations.

Copyright: (c) 2021 by the authors. Licensee MDPI, Basel, Switzerland. This article is an open access article distributed under the terms and conditions of the Creative Commons Attribution (CC BY) license (https:/ / creativecommons.org/licenses/by/ $4.0 /)$.

\begin{abstract}
Background/Aims: Curing Helicobacter pylori infection remains challenging for clinicians, as no proposed first-line therapy achieves bacterial eradication in all treated patients so that several patients need two or more consecutive treatments. Bacterial culture with antibiotics susceptibility testing is largely unachievable in Italy, and empiric second-line and rescue therapies are generally used. This study aimed to identify what eradication regimens perform better in Italy, following first-line therapy failure. Methods: We performed a literature search on PubMed for studies on standard therapy regimens used as second-line or rescue treatments performed in adult patients. Studies including modified drug combinations were not considered. Both intention-to-treat and perprotocol analyses were computed for each therapy subgroup. Results: Data from 35 studies with a total of 4830 patients were eventually considered. As a second-line therapy, Pylera ${ }^{\circledR}(90.6 \%)$ and a sequential regimen $(89.8 \%)$ achieved eradication rates significantly higher than other therapies. For third-line therapy, a levofloxacin-based regimen and Pylera ${ }^{\circledR}$ achieved comparable eradication rates $(88.2 \%$ vs. $84.7 \% ; p=0.2)$. Among therapies used as fourth (or more) attempts, Pylera ${ }^{\circledR}$ and a rifabutin-based therapy achieved $77.4 \%$ and $66.4 \%$ cure rates, respectively $(p=0.013)$. A therapy sequence based on the type of first-line therapy used was proposed. Conclusions: Data obtained through our review indicate that standard therapies for H. pylori eradication can be used when following an appropriate sequence, allowing clinicians to improve the cure rate without resorting to bacterial culture.
\end{abstract}

Keywords: Helicobacter pylori; rescue therapy; retreatment; antibiotic; therapy regimens

\section{Introduction}

Helicobacter pylori still remains a widely diffuse infection worldwide [1], and it is the main cause of both benign and malignant gastroduodenal diseases, including non-ulcer dyspepsia, peptic ulcers, gastric MALT-lymphoma and carcinoma, as well as interaction with non-steroidal anti-inflammatory drugs in causing gastroduodenal lesions [2,3]. Moreover, H. pylori plays a definite role in some extra-intestinal disorders, such as idiopathic thrombocytopenic purpura and idiopathic iron deficiency anemia [4,5], whilst the association with other diseases (neurological, dermatological, hematologic, ocular, cardiovascular, metabolic, allergic, and hepatobiliary diseases) deserves further investigation [6]. It is well known that $H$. pylori eradication definitely changes the natural history of peptic ulcer disease, in terms of recurrence and complications. Moreover, curing the infection reduces the risk of precancerous lesion evolution in the stomach. H. pylori eradication is not easily achieved, since several bacterial and host factors are involved in the therapeutic success, so that an antibiotic combination is required [7]. In detail, bacterial resistance towards 
antibiotics in H. pylori isolates is increasing [8]. Different therapy schedules, combining the few currently available antibiotics proven to be active against $H$. pylori strains in gastric juices, have been proposed. However, the best first-line therapies currently proposed achieve an eradication rate of around $90 \%$, so that about $10 \%$ of patients would need retreatment [9]. When considering the large prevalence of this infection worldwide, such a figure corresponds to millions of patients. Unfortunately, curing the infection following previous therapeutic attempts is definitively more difficult, largely due to secondary bacterial resistance towards the few available antibiotics for the eradication regimens, and the reduction of patients' compliance [10]. Current Italian and European guidelines suggest that a susceptibility-based therapy should be prescribed following two or more consecutive failures $[2,10]$. However, this approach is largely impracticable in clinical practice. Indeed, the need for dedicated microbiological laboratories, the challenges in isolating H. pylori from gastric biopsies, and the lack of constant correspondence between in vitro and in vivo results in terms of eradication, represent unsurmountable limitations for this approach [11,12]. Therefore, different empiric therapeutic regimens are currently used as rescue therapy, including a proton pump inhibitor (PPI) and levofloxacin-based, rifabutinbased, high-dose dual, sequential, concomitant, hybrid and bismuth-based therapies [13]. However, there is no one therapy sequence clearly proven to be more successful than another, causing uncertainty in choosing rescue therapies. What is the evidence regarding rescue therapies in Italy? To answer this question, we performed a review of the available literature with pooled data analysis.

\section{Results}

\subsection{Descriptive Analysis}

A total of 655 citations were found on PubMed. Following title and abstract reviews, 35 studies met the inclusion criteria, with 72 therapeutic arms and 4830 patients [14-48], whilst the others were ultimately excluded for different reasons, as listed in Figure 1. Overall, there were 26 therapeutic arms on a levofloxacin-based therapy, 25 on a bismuthbased quadruple therapy, including 21 studies with PPI and Pylera ${ }^{\circledR}$ (a standardized three-in-one capsule, containing bismuth subcitrate potassium (140 mg), metronidazole (125 mg), and tetracycline (125 mg), and 4 studies with standard PPI, bismuth, tetracycline, and metronidazole; 16 on rifabutin-based, and 5 on sequential therapy, whilst no study on concomitant, hybrid or high-dose dual therapy was available. Data from the second-line to the fifth attempt were available, and they were accordingly analyzed. The study design of 35 retrieved publications was prospective in 28 publications and retrospective in 7 , and the enrollment was multicenter in 23 and single-center in 12.

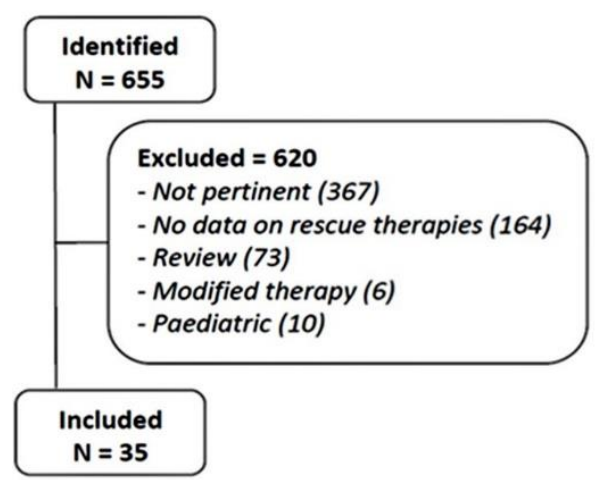

Figure 1. The flow chart of the literature review.

\subsection{Eradication Rates}

The eradication rates achieved by rescue treatments are reported in Table 1 at "per protocol" (PP) and at "intention-to-treatment" (ITT) analysis. As a second-line therapy, bismuth-based quadruple therapies (Pylera ${ }^{\circledR}$ or classic regimen) and a sequential regimen 
achieved the highest eradication rates. In detail, the cure rate following bismuth-based quadruple therapies was significantly higher than that of levofloxacin-based $(p<0.001)$ and rifabutin-based $(p<0.001)$ regimens, and similar to that of sequential therapy $(p=0.8)$. As a third-line therapy, a levofloxacin-based regimen and Pylera ${ }^{\circledR}$ achieved comparable eradication rates $(88.2 \%$ vs. $84.7 \% ; p=0.2)$, whilst the classic bismuth-based therapy achieved the lowest cure rate. Among the therapies used, three (or more) attempts failed; only rifabutin and Pylera ${ }^{\circledR}$ were tested in a significant number of patients, reporting an eradication rate of $66.4 \%$ and $77.4 \%$, respectively $(p=0.013)$. For the other regimens assessed, the number of patients evaluated was too low to be able to draw conclusions.

Table 1. Eradication rates at intention-to-treat (ITT) and per-protocol (PP) analysis.

\begin{tabular}{cccc}
\hline Therapy Regimen & $\begin{array}{c}\text { Second-Line } \\
\mathbf{\%}(\mathbf{9 5 \%} \mathbf{C I})\end{array}$ & $\begin{array}{c}\text { Third-Line } \\
\mathbf{\%}(\mathbf{9 5 \%} \mathbf{C I})\end{array}$ & $\begin{array}{c}\geq \text { Fourth-Line } \\
\mathbf{\%} \mathbf{( 9 5 \%} \text { CI) }\end{array}$ \\
\hline Levofloxacin (N) & 1273 & 151 & 63 \\
ITT & $78.7(76.5-81)$ & $84.7(79-90.5)$ & $74.6(63.8-85.3)$ \\
PP & $81.6(79.3-84)$ & $88.2(83-93.5)$ & $77(66.5-87.6)$ \\
Pylera-quadruple (N) & 873 & 222 & 164 \\
ITT & $90.6(88.6-92.5)$ & $88.2(84-92.5)$ & $77.4(71-83.8)$ \\
PP & $94(92.2-95.7)$ & $91.4(86.5-96.2)$ & $81.9(75.1-88.7)$ \\
Bismuth-quadruple & 154 & 27 & - \\
(N) & $92.8(88.7-96.9)$ & $51.8(33-70.6)$ & - \\
ITT & $98.6(95.9-100)$ & $58.3(38.6-78)$ & - \\
PP & 1009 & 428 & 301 \\
Rifabutin (N) & $65.9(62.9-68.8)$ & $77.3(73.3-81.3)$ & $66.4(61.1-71.7)$ \\
ITT & $76.4(73.6-79.2)$ & $82.1(78.3-85.8)$ & $73.3(67.8-78.2)$ \\
PP & 118 & 29 & 18 \\
Sequential (N) & $89.8(84.3-95.2)$ & $79.3(64.5-94)$ & $77.2(51.5-92.9)$ \\
ITT & $95.5(91.6-99.3)$ & $85.1(71.7-98.5)$ & $81.2(62.1-100)$ \\
PP & &
\end{tabular}

ITT: intention-to-treat; PP: per-protocol analysis; CI: confidence interval.

\section{Discussion}

H. pylori still remains a widely diffuse infection worldwide, with more than half the world's population being infected [1]. As is different from other infectious diseases, attempts to cure $H$. pylori infection with a single therapeutic attempt are unsuccessful in many patients. This largely depends on the increasing prevalence of primary antibiotic resistance [16]. Moreover, $H$. pylori eradication following therapy failures remains challenging for clinicians. Indeed, when an antibiotic was used, secondary resistance occurred in virtually all eradication failure strains, preventing its further use. This largely applies to clarithromycin, levofloxacin and metronidazole; whilst both primary and secondary resistance towards amoxicillin and tetracycline remain very low [49]. In 2017, the World Health Organization categorized clarithromycin-resistant H. pylori as a "high-priority" bacterium [50]. Moreover, bacterial culture availability for antibiotic susceptibility testing towards the few available antibiotics is scant, because it requires a dedicated microbiology laboratory with a specialized staff. Furthermore, H. pylori has slow bacterial growth and particular nutritional requirements, and culture-based methods are time-consuming (10 to 15 days), expensive, technically challenging, susceptible to inter-observer variability, and are not able to detect hetero-resistance status [11]. For these reasons, even tailored regimens were found to be no better than empiric therapies [51]. Therefore, standard therapies are empirically administered for $H$. pylori infection retreatment in clinical practice. This study evaluated the performance of different standard antibiotic regimens as rescue therapies for H. pylori eradication in Italy, and data from nearly five thousand patients were collected. We found that bismuth-based quadruple therapies and the sequential regimen achieved a similarly high eradication rate as second-line treatments, so that they might be administered in reversed sequence according to the initial regimen used. As far as the third-line therapy is concerned, better results were observed with levofloxacin-based 
and Pylera ${ }^{\circledR}$, with similar eradication rates of $85-88 \%$. Moreover, our data suggest that 14-day levofloxacin-based triple therapy could be more effective than the 10-day regimen, although the longer regimen was tested in only very few patients $(21 / 25,84 \%$ vs $1147 / 1452$, $78.9 \% ; p=0.7)$. However, this result is in agreement with data reported by a systematic review of international studies, showing a better performance for the 14 days regimen [52]. Therefore, the longer 14-day schedule should be preferred when choosing the levofloxacinbased regimen for rescue therapy. As for the fourth to fifth attempt, more consistent data are available only for Pylera ${ }^{\circledR}$ and rifabutin-based triple therapy, with a superiority of the quadruple regimen, even though the eradication rate was lower than $80 \%$. Following these considerations and based on available data, an 'empirical rescue package' might be proposed for clinical practice, as reported in Figure 2. A limitation of this therapeutic sequence is that all regimens, apart from bismuth-based quadruple therapies, include amoxicillin, so that it is not suitable for patients with a penicillin allergy. On the other hand, a tailored sequence has been reported for these patients [53]. Of note, data from a systematic review, including recent studies on rescue therapy for H. pylori infection performed in European countries, found similar results [54]. Therefore, the therapeutic sequence we proposed could also be applied in other geographic areas. Another limitation of our review was that it did not evaluate the quality of the included studies, so that the strength of information was not immediately evident. Moreover, the type of first-line therapy used in different studies before the second-line therapy was not considered in our analysis. Unexpectedly, no data were available on concomitant, hybrid and high-dose dual therapy. Interest in the last regimen was recently renewed, even as a first-line therapy [54]. Data of 3 meta-analyses found that dual therapy with high-dose PPI and amoxicillin achieved similar eradication rates to levofloxacin-based, rifabutin-based and bismuth-based quadruple therapies when used as rescue therapy, but with a significantly lower side-effect rate [55-57]. However, only data from Asian studies were considered, and no Italian data were available. Therefore, testing for high-dose dual therapy as rescue therapy in Italy is urged in order to increase the 'weapons in our therapeutic armamentarium'. Indeed, such a therapy might be introduced before rifabutin, aiming to limit the use to avoid bacterial resistance, when considering its usefulness for tuberculosis treatment in AIDS patients and its potential use for multidrugresistant pathogens such as the so-called ESKAPE organisms (an acronym for Enterococcus faecium, S. aureus, Klebsiella pneumoniae, Acinetobacter baumannii, Pseudomonas aeruginosa, and Enterobacter species) [58]. In conclusion, data obtained through our literature review found that standard therapies for $H$. pylori eradication can be used when following an appropriate sequence, allowing clinicians to improve the cure rate without resorting to bacterial culture.

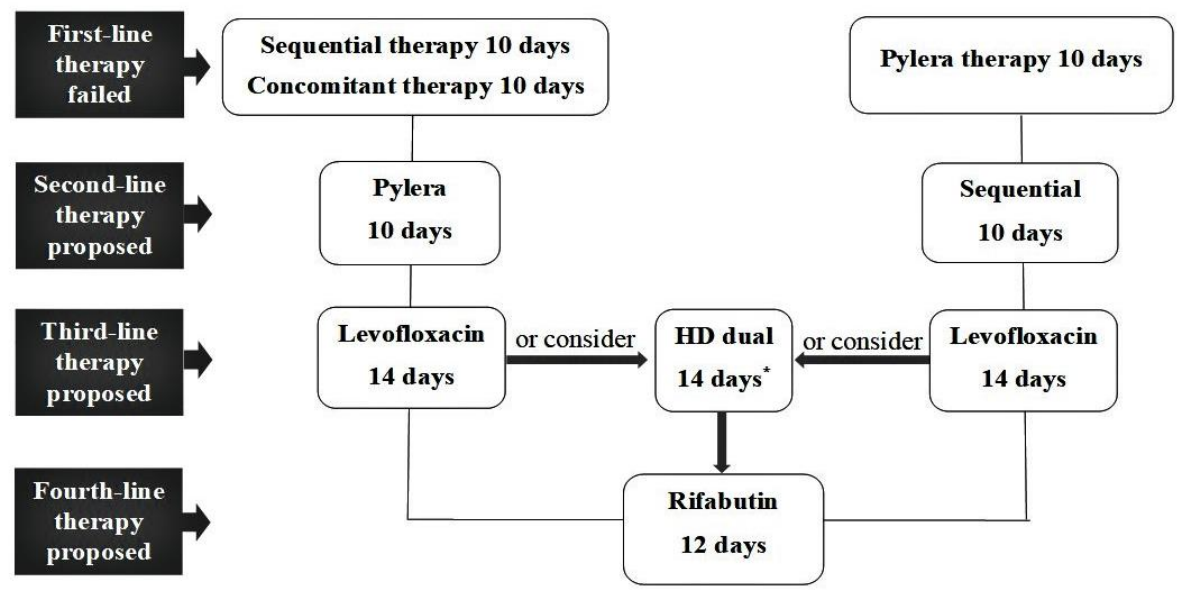

'HD: High-dose dual therapy with proton pump inhibitor and amoxicillin (see text).

Figure 2. The proposed therapies sequence. 


\section{Materials and Methods}

\subsection{Literature Review}

Separate computer-assisted searches were performed using PubMed. The search was performed on studies published in the last 15 years, from 1 January 2005 through to 31 December 2020, using the exploded medical subject heading terms "Helicobacter pylori" ("Helicobacter" OR "H. pylori") AND "therapy" (OR "treatment" OR "eradication") AND "Italy". A manual search of references in the retrieved full papers was performed to search for missed studies. Only therapeutic studies concerning rescue (at least 1 previous failed attempt) therapies by using the most common regimens prescribed were considered (Table 2). Studies including modified drug combinations (i.e., doxycycline, ciprofloxacin, moxifloxacin, azithromycin, etc.) were not considered. Following abstract evaluation, the full text of all relevant studies was retrieved, and manual searches of reference lists from identified relevant articles were performed to identify any additional studies that might have been missed. When more than one publication from the same investigator or group was available, only the most updated version including the entire sample size was considered. Studies that included pediatric patients, case series with fewer than 5 patients, and those in a language other than English were excluded. Two investigators (V.D.F. and A.Z.) independently extracted data according to a specifically designed database, and conflicting data were resolved by a third investigator (L.G.).

Table 2. Therapy regimens for Helicobacter pylori eradication.

\begin{tabular}{|c|c|c|}
\hline Therapy & Schedule & Duration \\
\hline Sequential & $\begin{array}{l}\text { Esomeprazole } 40 \mathrm{mg} \text { and amoxycillin } 1 \mathrm{~g} \text {, all } \\
\text { b.i.d for } 5 \text { days followed by: } \\
\text { Esomeprazole } 40 \mathrm{mg} \text {, clarithromycin } 500 \mathrm{mg} \text {, } \\
\text { and tinidazole } 500 \mathrm{mg} \text {, all b.i.d for } 5 \text { days }\end{array}$ & 10 days \\
\hline Pylera $^{\circledR}$ & 3 tablets q.i.d. and omeprazole $20 \mathrm{mg}$ b.i.d & 10 days \\
\hline Levofloxacin & $\begin{array}{c}\text { Esomeprazole } 40 \mathrm{mg} \text {, levofloxacin } 250 \mathrm{mg} \text {, and } \\
\text { amoxycillin } 1 \mathrm{~g} \text {, all b.i.d }\end{array}$ & 14 days \\
\hline High-dose dual & Esomeprazole $40 \mathrm{mg}$ and amoxycillin $1 \mathrm{~g}$, all t.i.d & 14 days \\
\hline Rifabutin & $\begin{array}{c}\text { Esomeprazole } 40 \mathrm{mg} \text { and amoxycillin } 1 \mathrm{~g} \text { b.i.d } \\
\text { plus rifabutin } 150 \mathrm{mg} \text { q.d }\end{array}$ & 12 days \\
\hline
\end{tabular}

b.i.d: twice a day; q.i.d: four times a day; t.i.d: three times a day; q.d: once a day.

\subsection{Statistical Analysis}

The eradication rates and their $95 \%$ confidence intervals at both intention-to-treat (ITT) and per-protocol (PP) analyses were computed for each subgroup. A comparison of cure rates was performed by using the Chi-squared test. Differences were considered significant at a 5\% probability level. Analyses were performed by using Statsoft version 7.1 (StatSoft Europe GmbH, 22301 Hamburg, Germany) program for Windows 10.

Author Contributions: Conceptualization and methodology, V.D.F. and A.Z.; resources and data curation, V.D.F. and A.Z.; writing - original draft preparation, V.D.F. and A.Z.; writing-review and editing, R.M., M.P., I.M.S. and G.F.; supervision, D.V. All authors have read and agreed to the published version of the manuscript.

Funding: This research received no external funding.

Data Availability Statement: Data available in a publicly accessible repository. The data presented in this study are openly available in the PubMed database.

Acknowledgments: The authors received no financial support for the research or publication of this article.

Conflicts of Interest: The authors declare no conflict of interest. 


\section{References}

1. Leja, M.; Grinberga-Derica, I.; Bilgilier, C.; Steininger, C. Review: Epidemiology of Helicobacter pylori infection. Helicobacter 2019, 24 (Suppl. 1), e12635. [CrossRef] [PubMed]

2. Zagari, R.M.; Romano, M.; Ojetti, V.; Stockbrugger, R.; Gullini, S.; Annibale, B.; Farinati, F.; Ierardi, E.; Maconi, G.; Rugge, M.; et al. Guidelines for the management of Helicobacter pylori infection in Italy: The III Working Group Consensus Report. Dig. Liver Dis. 2015, 47, 903-912. [CrossRef] [PubMed]

3. Abrignani, M.G.; Gatta, L.; Gabrielli, D.; Milazzo, G.; de Francesco, V.; de Luca, L.; Francese, M.; Imazio, M.; Riccio, E.; Rossini, R.; et al. Gastroprotection in patients on antiplatelet and/or anticoagulant therapy: A position paper of National Association of Hospital Cardiologists (ANMCO) and the Italian Association of Hospital Gastroenterologists and Endoscopists (AIGO). Eur. J. Intern. Med. 2021, 85, 1-13. [CrossRef] [PubMed]

4. Pezeshki, S.M.S.; Saki, N.; Ghandali, M.V.; Ekrami, A.; Avarvand, A.Y. Effect of Helicobacter pylori eradication on patients with ITP: A meta-analysis of studies conducted in the Middle East. Blood Res. 2021, 56, 38-43. [CrossRef]

5. Elli, L.; Norsa, L.; Zullo, A.; Carroccio, A.; Girelli, C.; Oliva, S.; Romano, C.; Leandro, G.; Bellini, M.; Marmo, R.; et al. Diagnosis of chronic anaemia in gastrointestinal disorders: A guideline by the Italian Association of Hospital Gastroenterologists and Endoscopists (AIGO) and the Italian Society of Paediatric Gastroenterology Hepatology and Nutrition (SIGENP). Dig. Liver Dis. 2019, 51, 471-483. [CrossRef] [PubMed]

6. Gravina, A.G.; Priadko, K.; Ciamarra, P.; Granata, L.; Facchiano, A.; Miranda, A.; Dallio, M.; Federico, A.; Romano, M. ExtraGastric Manifestations of Helicobacter pylori Infection. J. Clin. Med. 2020, 9, 3887. [CrossRef] [PubMed]

7. Zullo, A.; de Francesco, V.; Hassan, C. Predicting Helicobacter pylori eradication: How to teach an old dog new tricks! J. Clin. Gastroenterol. 2012, 46, 259-261. [CrossRef]

8. Saracino, I.M.; Fiorini, G.; Zullo, A.; Pavoni, M.; Saccomanno, L.; Vaira, D. Trends in Primary Antibiotic Resistance in H. pylori Strains Isolated in Italy between 2009 and 2019. Antibiotics 2020, 9, 26. [CrossRef] [PubMed]

9. De Francesco, V.; Bellesia, A.; Ridola, L.; Manta, R.; Zullo, A. First-line therapies for Helicobacter pylori eradication: A critical reappraisal of updated guidelines. Ann. Gastroenterol. 2017, 30, 373-379. [CrossRef]

10. Malfertheiner, P.; Megraud, F.; O’Morain, C.A.; Gisbert, J.P.; Kuipers, E.J.; Axon, A.T.; Bazzoli, F.; Gasbarrini, A.; Atherton, J.; Graham, D.Y.; et al. Management of Helicobacter pylori infection-the Maastricht V/Florence Consensus Report. Gut 2017, 66, 6-30. [CrossRef]

11. Zullo, A.; Hassan, C.; Lorenzetti, R.; Winn, S.; Morini, S. A clinical practice viewpoint: To culture or not to culture Helicobacter pylori? Dig. Liver Dis. 2003, 35, 357-361. [CrossRef]

12. De Francesco, V.; Zullo, A.; Fiorini, G.; Saracino, I.M.; Pavoni, M.; Vaira, D. Role of MIC levels of resistance to clarithromycin and metronidazole in Helicobacter pylori eradication. J. Antimicrob. Chemother. 2019, 74, 772-774. [CrossRef] [PubMed]

13. Muñoz, N.; Sánchez-Delgado, J.; Baylina, M.; Puig, I.; López-Góngora, S.; Suarez, D.; Calvet, X. Systematic review, meta-analysis, and meta-regression: Successful second-line treatment for Helicobacter pylori. Helicobacter 2018, 23, e12488. [CrossRef] [PubMed]

14. Saracino, I.M.; Pavoni, M.; Zullo, A.; Fiorini, G.; Saccomanno, L.; Lazzarotto, T.; Antonelli, G.; Cavallo, R.; Borghi, C.; Vaira, D. Rifabutin-based triple therapy or bismuth-based quadruple regimen as rescue therapies for Helicobacter pylori infection. Eur. J. Intern. Med. 2020, 81, 50-53. [CrossRef] [PubMed]

15. Saracino, I.M.; Pavoni, M.; Zullo, A.; Fiorini, G.; Saccomanno, L.; Lazzarotto, T.; Antonelli, G.; Cavallo, R.; Borghi, C.; Vaira, D. Rescue Therapies for Helicobacter pylori infection in foreign patients treated in Italy. J. Clin. Gastroenterol. 2020. [CrossRef]

16. Saracino, I.M.; Pavoni, M.; Zullo, A.; Fiorini, G.; Saccomanno, L.; Lazzarotto, T.; Cavallo, R.; Antonelli, G.; Vaira, D. Antibiotic resistance and therapy outcome in $H$. pylori eradication failure patients. Antibiotics 2020, 9, 121.

17. Mascellino, M.T.; Oliva, A.; Miele, M.C.; de Angelis, M.; Bruno, G.; Severi, C. Secondary antibiotic resistance, correlation between genotypic and phenotypic methods and treatment in Helicobacter pylori infected patients: A retrospective study. Antibiotics 2020, 9, 549. [CrossRef]

18. Ribaldone, D.G.; Fagoonee, S.; Astegiano, M.; Durazzo, M.; Morgando, A.; Sprujevnik, T.; Giordanino, C.; Baronio, M.; de Angelis, C.; Saracco, G.M.; et al. Rifabutin-based rescue therapy for Helicobacter pylori eradication: A long-term prospective study in a large cohort of difficult-to-treat patients. J. Clin. Med. 2019, 8, 199. [CrossRef]

19. Tursi, A.; Franceschi, M.; Allegretta, L.; Savarino, E.; de Bastiani, R.; Elisei, W.; Baldassarre, G.; Ferronato, A.; Scida, S.; Miraglia, C.; et al. Effectiveness and safety of Pylera®in patients infected by Helicobacter pylori: A multicenter, retrospective, real-life study. Dig. Dis. 2018, 36, 264-268. [CrossRef]

20. Fiorini, G.; Zullo, A.; Vakil, N.; Saracino, I.M.; Ricci, C.; Castelli, V.; Gatta, L.; Vaira, D. Rifabutin triple therapy is effective in patients with multidrug-resistant strains of Helicobacter pylori. J. Clin. Gastroenterol. 2018, 52, 137-140. [CrossRef]

21. Di Ciaula, A.; Scaccianoce, G.; Venerito, M.; Zullo, A.; Bonfrate, L.; Rokkas, T.; Portincasa, P. Eradication rates in Italian subjects heterogeneously managed for Helicobacter pylori infection. Time to abandon empiric treatments in Southern Europe. J. Gastrointest. Liver Dis. 2017, 26, 129-137. [CrossRef] [PubMed]

22. Zagari, R.M.; Romiti, A.; Ierardi, E.; Gravina, A.G.; Panarese, A.; Grande, G.; Savarino, E.; Maconi, G.; Stasi, E.; Eusebi, L.H.; et al. The "three-in-one" formulation of bismuth quadruple therapy for Helicobacter pylori eradication with or without probiotics supplementation: Efficacy and safety in daily clinical practice. Helicobacter 2018, 23, e12502. [CrossRef] [PubMed]

23. Fiorini, G.; Saracino, I.M.; Zullo, A.; Gatta, L.; Pavoni, M.; Vaira, D. Rescue therapy with bismuth quadruple regimen in patients with Helicobacter pylori-resistant strains. Helicobacter 2017, 22, e12448. [CrossRef] [PubMed] 
24. Zullo, A.; de Francesco, V.; Bellesia, A.; Vassallo, R.; D’Angelo, A.; Scaccianoce, G.; Sacco, R.; Bresci, G.; Eramo, A.; Tanzilli, A.; et al. Bismuth-based quadruple therapy following $H$. pylori eradication failures: A multicenter study in clinical practice. J. Gastrointest. Liver Dis. 2014, 26, 225-229. [CrossRef] [PubMed]

25. Tursi, A.; di Mario, F.; Franceschi, M.; de Bastiani, R.; Elisei, W.; Baldassarre, G.; Ferronato, A.; Grillo, S.; Landi, S.; Zamparella, M.; et al. New bismuth-containing quadruple therapy in patients infected with Helicobacter pylori: A first Italian experience in clinical practice. Helicobacter 2017, 22, e12371. [CrossRef]

26. De Francesco, V.; Ridola, L.; Hassan, C.; Bellesia, A.; Alvaro, D.; Vaira, D.; Zullo, A. Two-week Triple Therapy with either Standard or high-dose esomeprazole for first-line H. pylori eradication. J. Gastrointest. Liver Dis. 2016, 25, 147-150. [CrossRef]

27. Ciccaglione, A.F.; Tavani, R.; Grossi, L.; Cellini, L.; Manzoli, L.; Marzio, L. Rifabutin containing triple therapy and rifabutin with bismuth containing quadruple therapy for third-line treatment of Helicobacter pylori infection: Two pilot studies. Helicobacter 2016, 21, 375-381. [CrossRef]

28. Ierardi, E.; Giangaspero, A.; Losurdo, G.; Giorgio, F.; Amoruso, A.; de Francesco, V.; Di Leo, A.; Principi, M. Quadruple rescue therapy after first and second-line failure for Helicobacter pylori treatment: Comparison between two tetracycline-based regimens. J. Gastrointest. Liver Dis. 2014, 23, 367-370. [CrossRef]

29. Zullo, A.; Ridola, L.; Efrati, C.; Giorgio, F.; Nicolini, G.; Cannaviello, C.; Alvaro, D.; Hassan, C.; Gatta, L.; Francesco, V.D. Firstand second-line Helicobacter pylori eradication with modified sequential therapy and modified levofloxacin-amoxicillin-based triple therapy. Ann. Gastroenterol. 2014, 27, 357-361.

30. Zullo, A.; Scaccianoce, G.; de Francesco, V.; Ruggiero, V.; D’Ambrosio, P.; Castorani, L.; Bonfrate, L.; Vannella, L.; Hassan, C.; Portincasa, P. Concomitant, sequential, and hybrid therapy for H. pylori eradication: A pilot study. Clin. Res. Hepatol. Gastroenterol. 2013, 37, 647-650. [CrossRef]

31. Fiorini, G.; Vakil, N.; Zullo, A.; Saracino, I.M.; Castelli, V.; Ricci, C.; Zaccaro, C.; Gatta, L.; Vaira, D. Culture-based selection therapy for patients who did not respond to previous treatment for Helicobacter pylori infection. Clin. Gastroenterol. Hepatol. 2013, 101, 507-510. [CrossRef]

32. Federico, A.; Nardone, G.; Gravina, A.G.; Iovene, M.R.; Miranda, A.; Compare, D.; Pilloni, P.A.; Rocco, A.; Ricciardiello, L.; Marmo, R.; et al. Efficacy of 5-day levofloxacin-containing concomitant therapy in eradication of Helicobacter pylori infection. Gastroenterology 2012, 143, 55-61. [CrossRef] [PubMed]

33. Sereni, G.; Azzolini, F.; Camellini, L.; Formisano, D.; Decembrino, F.; Iori, V.; Tioli, C.; Cavina, M.; Di Mario, F.; Bedogni, G.; et al. Efficacy of a therapeutic strategy for eradication of Helicobacter pylori infection. World J. Gastronterol. 2012, 18, 4542-4548. [CrossRef] [PubMed]

34. D'Elios, M.M.; Silvestri, E.; Emmi, G.; Barnini, T.; Prisco, D. Helicobacter pylori: Usefulness of an empirical fourth-line rifabutinbased regimen. Expert Rev. Gastroenterol. Hepatol. 2012, 6, 437-439. [CrossRef]

35. Ojetti, V.; Bruno, G.; Ainora, M.E.; Gigante, G.; Rizzo, G.; Roccarina, D.; Gasbarrini, A. Impact of Lactobacillus reuteri supplementation on anti-Helicobacter pylori levofloxacin-based second-line therapy. Gastroenterol. Res. Pract. 2012, $2012,740381$. [CrossRef]

36. Manfredi, M.; Bizzarri, B.; de'Angelis, G.L. Helicobacter pylori infection: Sequential therapy followed by levofloxacin-containing triple therapy provides a good cumulative eradication rate. Helicobacter 2012, 17, 246-253. [CrossRef]

37. Urgesi, R.; Pelecca, G.; Cianci, R.; Masini, A.; Zampaletta, C.; Riccioni, M.E.; Faggiani, R. Helicobacter pylori infection: Is sequential therapy superior to standard triple therapy? A single-centre Italian study in treatment-naive and non-treatment-naive patients. Can. J. Gastroenterol. 2011, 25, 315-318. [CrossRef]

38. Zullo, A.; de Francesco, V.; Manes, G.; Scaccianoce, G.; Cristofari, F.; Hassan, C. Second-line and rescue therapies for Helicobacter pylori eradication in clinical practice. J. Gastrointestin. Liver Dis. 2010, 19, 131-134.

39. Zullo, A.; Hassan, C.; Cristofari, F.; Iegri, C.; de Francesco, V. How to manage Helicobacter pylori after sequential therapy failure? J. Clin. Gastroenterol. 2010, 44, 459-460. [CrossRef] [PubMed]

40. Pontone, S.; Standoli, M.; Angelini, R.; Pontone, P. Efficacy of H. pylori eradication with a sequential regimen followed by rescue therapy in clinical practice. Dig. Liver Dis. 2010, 42, 541-543. [CrossRef]

41. Di Caro, S.; Franceschi, F.; Mariani, A.; Thompson, F.; Raimondo, D.; Masci, E.; Testoni, A.; La Rocca, E.; Gasbarrini, A. Second-line levofloxacin-based triple schemes for Helicobacter pylori eradication. Dig. Liver Dis. 2019, 41, 480-485. [CrossRef]

42. Perna, F.; Zullo, A.; Ricci, C.; Hassan, C.; Morini, S.; Vaira, D. Levofloxacin-based triple therapy for Helicobacter pylori re-treatment: Role of bacterial resistance. Dig. Liver Dis. 2007, 39, 1001-1005. [CrossRef] [PubMed]

43. Tursi, A.; Elisei, W.; Brandimarte, G.; Giorgetti, G.M.; Modeo, M.E.; Aiello, F. Effect of lactoferrin supplementation on the effectiveness and tolerability of a 7-day quadruple therapy after failure of a first attempt to cure Helicobacter pylori infection. Med. Sci. Monit. 2007, 13, CR187-CR190. [PubMed]

44. Marzio, L.; Coraggio, D.; Capodicasa, S.; Grossi, L.; Cappello, G. Role of the preliminary susceptibility testing for initial and after failed therapy of Helicobacter pylori infection with levofloxacin, amoxicillin, and esomeprazole. Helicobacter 2006, 11, $237-242$. [CrossRef]

45. Giannini, E.G.; Bilardi, C.; Dulbecco, P.; Mamone, M.; Santi, M.L.; Testa, R.; Mansi, C.; Savarino, V. A study of 4- and 7-day triple therapy with rabeprazole, high-dose levofloxacin and tinidazole rescue treatment for Helicobacter pylori eradication. Aliment. Pharmacol. Ther. 2006, 23, 281-287. [CrossRef] [PubMed] 
46. Zullo, A.; de Francesco, V.; Hassan, C.; Panella, C.; Morini, S.; Ierardi, E. Second-line treatment for Helicobacter pylori eradication after sequential therapy failure: A pilot study. Therapy 2006, 3, 251-254. [CrossRef] [PubMed]

47. Gatta, L.; Zullo, A.; Perna, F.; Ricci, C.; de Francesco, V.; Tampieri, A.; Bernabucci, V.; Cavina, M.; Hassan, C.; Ierardi, E.; et al. A 10-day levofloxacin-based triple therapy in patients who have failed two eradication courses. Aliment. Pharmacol. Ther. 2005, 22, 45-49. [CrossRef] [PubMed]

48. Toracchio, S.; Capodicasa, S.; Soraja, D.B.; Cellini, L.; Marzio, L. Rifabutin based triple therapy for eradication of H. pylori primary and secondary resistant to tinidazole and clarithromycin. Dig. Liver Dis. 2005, 37, 33-38. [CrossRef]

49. Hu, Y.; Zhu, Y.; Lu, N.H. Novel and Effective Therapeutic Regimens for Helicobacter pylori in an Era of Increasing Antibiotic Resistance. Front. Cell. Infect. Microbiol. 2017, 7, 168. [CrossRef]

50. Tacconelli, E.; Carrara, E.; Savoldi, A.; Harbarth, S.; Mendelson, M.; Monnet, D.L.; Pulcini, C.; Kahlmeter, G.; Kluytmans, J.; Carmeli, Y.; et al. WHO Pathogens Priority List Working Group. Discovery, research, and development of new antibiotics: The WHO priority list of antibiotic-resistant bacteria and tuberculosis. Lancet. Infect. Dis. 2018, 18, 318-327. [CrossRef]

51. Gisbert, J.P. Empirical or susceptibility-guided treatment for Helicobacter pylori infection? A comprehensive review. Ther. Adv. Gastroenterol. 2020, 13, 1-16. [CrossRef]

52. Gisbert, J.P. Optimization strategies aimed to increase the efficacy of Helicobacter pylori eradication therapies with quinolones. Molecules 2020, 25, 5084. [CrossRef]

53. Moellering, R. A cause for worldwide concern. N. Engl. J. Med. 2010, 363, 2377-2379. [CrossRef] [PubMed]

54. De Francesco, V.; Zullo, A.; Manta, R.; Gatta, L.; Fiorini, G.; Saracino, I.M.; Vaira, D. Helicobacter pylori eradication following first-line treatment failure in Europe: What, how and when chose among different standard regimens? A systematic review. Eur. J. Gastroenterol. Hepatol. 2021. [CrossRef] [PubMed]

55. Zullo, A. The current role of dual therapy for treatment of Helicobacter pylori: Back to the future? Eur. J. Gastroenterol. Hepatol. 2020, 32, 555-556. [CrossRef] [PubMed]

56. Yang, J.; Zhang, Y.; Fan, L.; Zhu, Y.J.; Wang, T.Y.; Wang, X.W.; Chen, D.F.; Lan, C.H. Eradication efficacy of modified dual therapy compared with bismuth-containing quadruple therapy as a first-line treatment of Helicobacter pylori. Am. J. Gastroenterol. 2019, 114, 437-445. [CrossRef] [PubMed]

57. Gao, C.P.; Zhang, D.; Zhang, T.; Wang, J.X.; Han, S.X.; Graham, D.Y.; Lu, H. PPI-amoxicillin dual therapy for Helicobacter pylori infection: An update based on a systematic review and meta-analysis. Helicobacter 2020, 25, e12692. [CrossRef]

58. Zhu, Y.J.; Zhang, Y.; Wang, T.Y.; Zhao, J.T.; Zhao, Z.; Zhu, J.R.; Lan, C.H. High dose PPI-amoxicillin dual therapy for the treatment of Helicobacter pylori infection: A systematic review with meta-analysis. Ther. Adv. Gastroenterol. 2020, 13, 1-12. [CrossRef] 